\title{
Fractal analysis of fracture systems in Upper Triassic Dolomites in Žumberak Mountain, Croatia
}

The Mining-Geology-Petroleum Engineering Bulletin UDC: $550.8: 552.1$ DOI: $10.17794 /$ rgn.2017.3.1

Original scientific paper

\author{
Ivica Pavičić'; Ivan Dragičević́; ; Tatjana Vlahović́; Tonći Grgasović4 \\ ${ }^{1}$ Faculty of Mining, Geology and Petroleum Engineering (Pierottijeva 6, 10 000, Zagreb, Croatia) \\ ${ }^{2}$ Faculty of Mining, Geology and Petroleum Engineering (Pierottijeva 6, 10 000, Zagreb, Croatia) \\ ${ }^{3}$ Croatian Natural History Museum (Demetrova 1, 10 000, Zagreb, Croatia) \\ ${ }^{4}$ Croatian Geological Survey (Milana Sachsa 2, 10 000, Zagreb)
}

\begin{abstract}
This paper presents the results of fractal analysis of fracture systems in upper Triassic dolomites in Žumberak Mountain, Croatia. Mechanical rock characteristics together with structural and diagenetic processes result in fracture systems that can be considered as fractals. They are scale-invariant in a specific range of scales. The distribution of fractures can be described with power law distribution and fractal dimension. Fractal dimension is a measure of how fractures fill the space. Fractal dimension can be estimated from photographs of outcrops by converting photographs to binary photographs. Binary photo display only black (rock or fractures) and white (fractures or rock). Fractal dimension is then estimated based on the box-counting method. In this paper, we present results of fractal analysis from three outcrops. The results are very similar to previously published results from outcrops of dolomites in Slovenia. The obtained fractal dimensions are in the range 2,69-2,78 and depend on how fracture systems are distributed in the outcrop. Lower values indicate a smaller number of fractures and a higher significance of larger fractures. Higher values indicate the distribution of more similarly sized fractures throughout the whole outcrop. Fractal dimension is a very significant parameter and in the rock fracture system characterisation sense, it describes how fractures are distributed in the outcrop. It can be used in discrete fracture network modelling if spatial distribution of fractures is represented with power law distribution.
\end{abstract}

Keywords

Fractured rocks, Triassic dolomites, fractal dimension, Žumberak Mountain

\section{Introduction}

In northwestern Croatia, carbonate rock has a great hydrogeological potential with relatively low primary porosity but considerable secondary i.e. fracture porosity (Dragičević et al., 2014). These are mainly dolomites of Upper Triassic age that are characterized by significant thicknesses and significant surface and subsurface distribution. As a result, the shallower structures regularly contain groundwater of high quality and the greater depths contain geothermal water or even hydrocarbons. Although, these dolomites have great hydrogeological potential, their porosity distribution was never analyzed.

The spatial distribution of fractures and fracture systems have been described with power-law distribution as fractals (Antonellini \& Mollema, 2000; Agosta \& Tondi, 2010; Rustichelli et al., 2013; Panza et al., 2015; Zambrano et al., 2016; Antonellini \& Mollema, 2016; Bauer et al., 2016). Fracture systems in upper Triassic dolomites in Slovenia are also recognized as fractal objects with power-law distribution and fractal dimension

Corresponding author: Ivica Pavičić

Ivica.pavicic@rgn.hr that were estimated from photographs of outcrops (Verbovšek, 2009). In this research, a different method is presented, where photographs are converted to binary photographs (black \& white) and then fractal dimensions of fractures are estimated. The results are very close to results that are obtained from photographs that are manually digitalized (Verbovšek, 2009). Although this method is faster than manually digitalizing fracture traces on photographs, it is more susceptible to errors. This method of estimating the fractal dimension is very fast and gives a good generalized result on the fractal dimension of fracture distribution.

The researched area is located within the Žumberak Mountains, which together with the Samobor Mountains and Gorjanci in Slovenia make a unique geomorphological unit (see Figure 1). The area is located in the western part of northwestern Croatian, in the transition from plains to a mountainous, karstic region. The territory of Žumberak and Samobor Mountains represents the geographical northeastern border of the Dinarides mountain range.

This research area was chosen because the main lithological unit in Žumberak Mountain is the Upper Triassic dolomites (Grgasović, 1997; Grgasović, 1998). These 


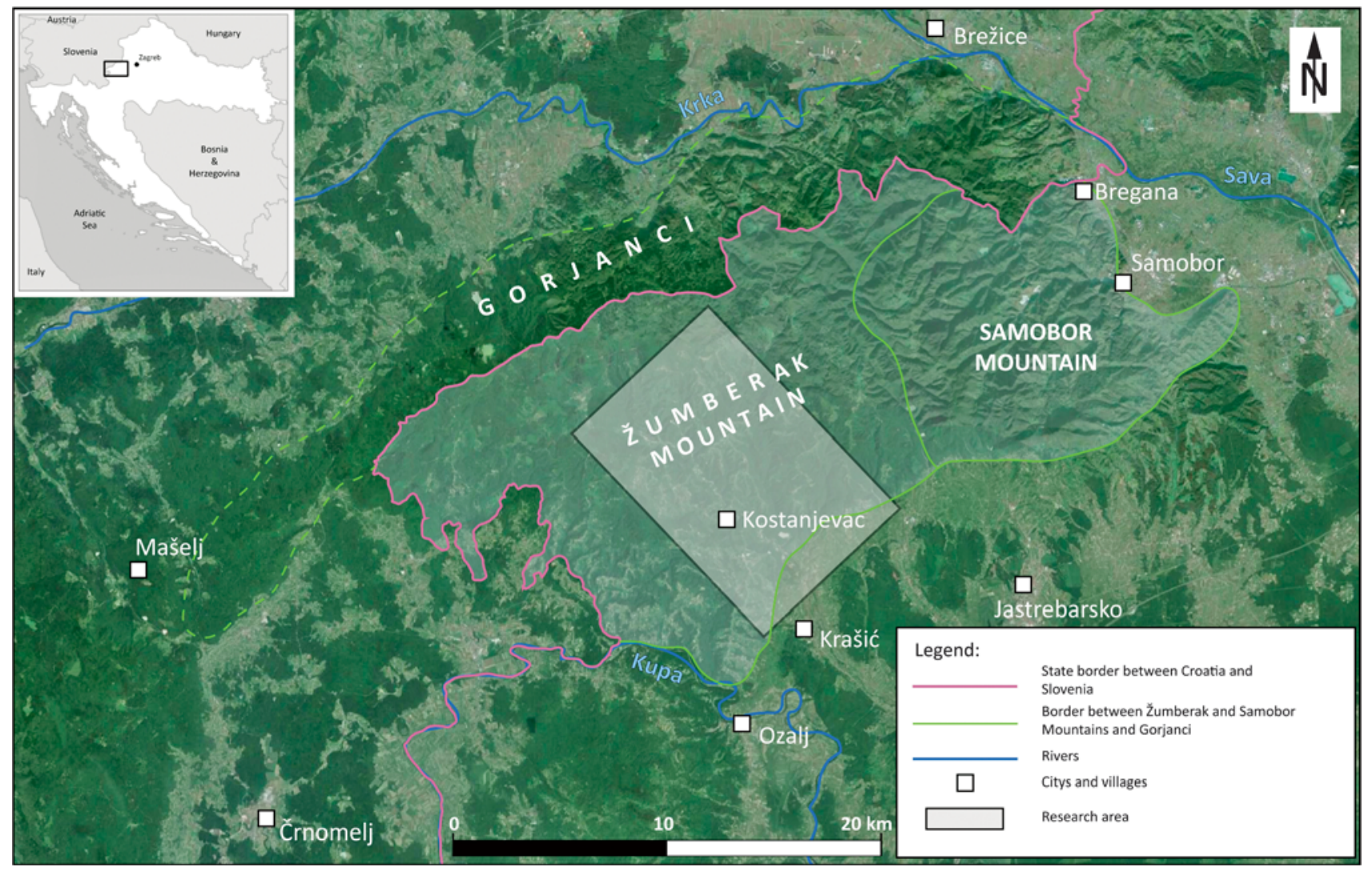

Figure 1: The geographical position of geomorphological areas of the Žumberak and Samobor Mountains and Gorjanci in the Republic of Slovenia

dolomites are characterized with relatively low primary porosity but significant fracture porosity, which give them great hydrogeological potential (Dragičević et al., 2014). Also. previous stratigraphic (Grgasović, 1997; Grgasović, 1998), structural (Prtoljan, 2001) and hydrogeological research (Dragičević et al., 1997; Brkić et al., 2002; Vujnović, 2010, Frangen, 2013; Dragičević et al, 2014; Pavičić, 2014), conducted in this area, represents a solid background for this research. The aim of the research was to prove that the spatial distribution of fractures and fracture systems in the Upper Triassic dolomites could be described with "power-law" distribution and fractal dimension. Three sites were selected where detailed photos of the outcrops were taken and their fractal dimensions were estimated using the boxcounting method. The analyses were performed to show that the fractures in the Upper Triassic dolomites are natural fractals and that their distribution in the Upper Triassic dolomites can be approximated by the "powerlaw" function or fractal distribution.

\section{Geological settings of Upper Triassic dolomites in Žumberak Mountain}

\subsection{Stratigraphic and sedimentological settings}

The Upper Triassic dolomites $\left(T_{3}\right)$ (see Figure 2) are the most important lithological unit in the geological structure of Žumberak (see Figures 3 and 4). They are distributed throughout most of the study area (see Figure 3). They are composed of mainly early diagenetic dolomites, in some areas partially recrystallized into "sugary" dolomites (Grgasović, 1998). They are light gray to dark gray in color, depending on the content of clayey and organic components. Grgasović (1998) singled out three formations within the Upper Triassic dolomites ("Slapnica", "Glavni dolomit" and "Posinak") and three members ("Vranjak", "Drenovac" and "Kalje") (see Figure 4). In the lower area, the "Slapnica" formation is singled out. It is of Carnian age, represented by more or less uniform cyclical alternations of dolomicrite, fenestral dolomicrite and stromatolitic dolomites (see Figure 4, photo 1), deposited in a peritidal environment (Grgasović, 1998). Layered surfaces are clearly differentiated. In the lower part of the formation, the member "Vranjak" is characterized by thin layers of yellowish shale, reflecting "Rabelj events" (Grgasović, 1998). In the upper area, the member "Drenovac" is characterized by a high content of organic matter, interbeds of kerogen shale and laminite, and the occurrence of coal (see Figure 4, photo 2) (Grgasović, 1998). The sedimentation environments are anoxic closed lagoons. The massive deposits of the formation "Glavni dolomit" of Norian - Late Rhaetian age follow, characterized by more or less irregular vertical and lateral alternations of dolomicrite, fenestral dolomicrite (see Figure 4, photo 

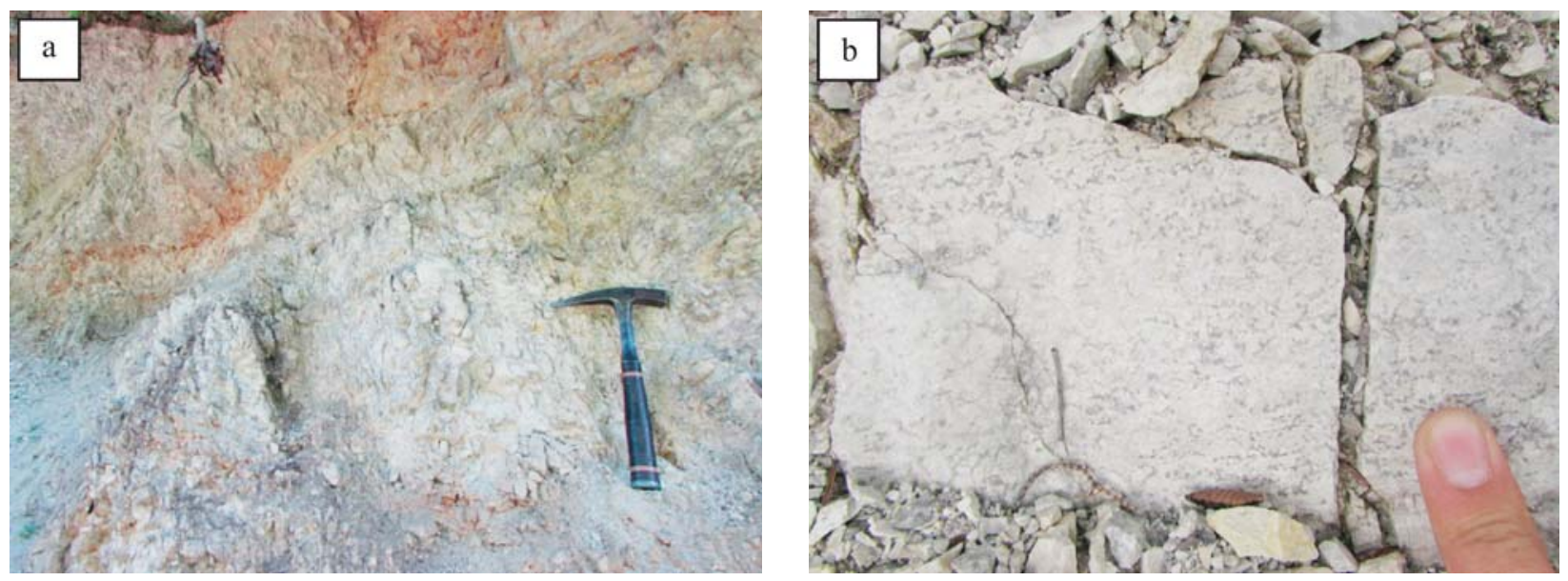

Figure 2. a): Outcrops of fractures dolomites from the formation "Slapnica“" (Slapnica Valley);

b) Outcrop of "Main dolomite" with clearly visible fenestrae (the road from the mouth of Slapnice towards the village of Kalje)

3) and dark fine-laminated stromatolites (see Figure 4, photo 3) (Grgasović, 1998). These stromatolites are the most distinctive characteristic of the formation "Glavni dolomit". The formation "Posinak" of Rhaetian age is characterized by well-bedded dolomicrites, with intermittent horizontal stromatolite lamination, and subordinated fenestral dolomicrites. Dolomitic limestone and limestone are also present. The sedimentation environment is peritidal, with pronounced deepening in comparison with underlying formations. The border with Lower Jurassics is conformal (Grgasović, 1998). The thickness of Upper Triassic dolomites is estimated at about 1570 m (Grgasović, 1998).

\subsection{Tectonic and structural settings}

The rocks that comprise the Žumberak Mountains endured multiple phases of tectonic development throughout their geological past. Such tectonic development along with diagenetic processes resulted in significant secondary porosity in the Upper Triassic dolomites. Structures of Žumberak components mostly have NW-SE strikes with a vergence to the SW (see Figure 3) (Prtoljan, 2001). They are mutually separated from each other by faults with NE-SW to E-W strikes, amidst a prevailing shift along the strike and reverse fault - nappes with NW-SE strikes (see Figure 3). Along the southern edge of Žumberak, there is a fault of the so-called "Zagreb-Zemplen" system (Pamić \& Tomljenović, 1998), which continues to the east into the foot of Medvednica Mountain.

From the Middle Eocene to the Late Oligocene, strong compression took place in the Dinarides and even in Žumberak which created a system of reverse faults/nappes and imbricated structures with NW-SE strikes, parallel to so-called "Sava nappes" (Prtoljan, 2001). This tectonic compression phase brought carbonate rocks of Triassic and Jurassic age into a thrust contact with the Upper Cretaceous clastics (see Figure 3). However, re- cent structural settings are the result of the Upper Miocene and recent tectonic movements (Prtoljan, 2001). Reverse faults and folds, formed during earlier tectonic phases, are displaced by a diagonal shift, with a NE-SW strike (see Figure 3). Structural relations of the SW part of the Žumberak Triassic carbonate sequence are somewhat more complicated because the NE-SW strike-slip faults intersect and shifts faults of the "Sava nappes" (see Figure 3) (Prtoljan, 2001).

The relationship of these systems of faults causes uneven shifting with a rotation of tectonic blocks in the hanging wall of the formed "nappe". The faults (or "nappes") with NW-SE strikes are reactivated and constitute a set of conjugated pairs with the newly formed NE-SW faults. (Prtoljan, 2001).

The faults with N-S strikes are the youngest faults of the structural settings. Although without regional significance, they contribute to the complexity of the structural settings (Prtoljan, 2001). The faults are of normal character with a relatively steep fault plane (between $75^{\circ}$ and $90^{\circ}$ ) (Prtoljan, 2001). The strike of individual structures may intermittently be different than those described above, which is the result of local stress.

\section{Fractals and Fractal geometry in geology}

Geological processes and phenomena exist in a large range of scales, from crystal scale to regional scale. Accordingly, it can be said that they are scale independent. The scale independence is proven by the fact that if a photo of some geological phenomena lacks an object of known dimensions (a geologist's hammer, coins, and the like) then it is almost impossible to conclude whether the picture depicts something in $\mathrm{mm}$ or $\mathrm{km}$ scale. This feature is called "self-similarity" and objects, processes or phenomena characterized by this property are called fractals. 


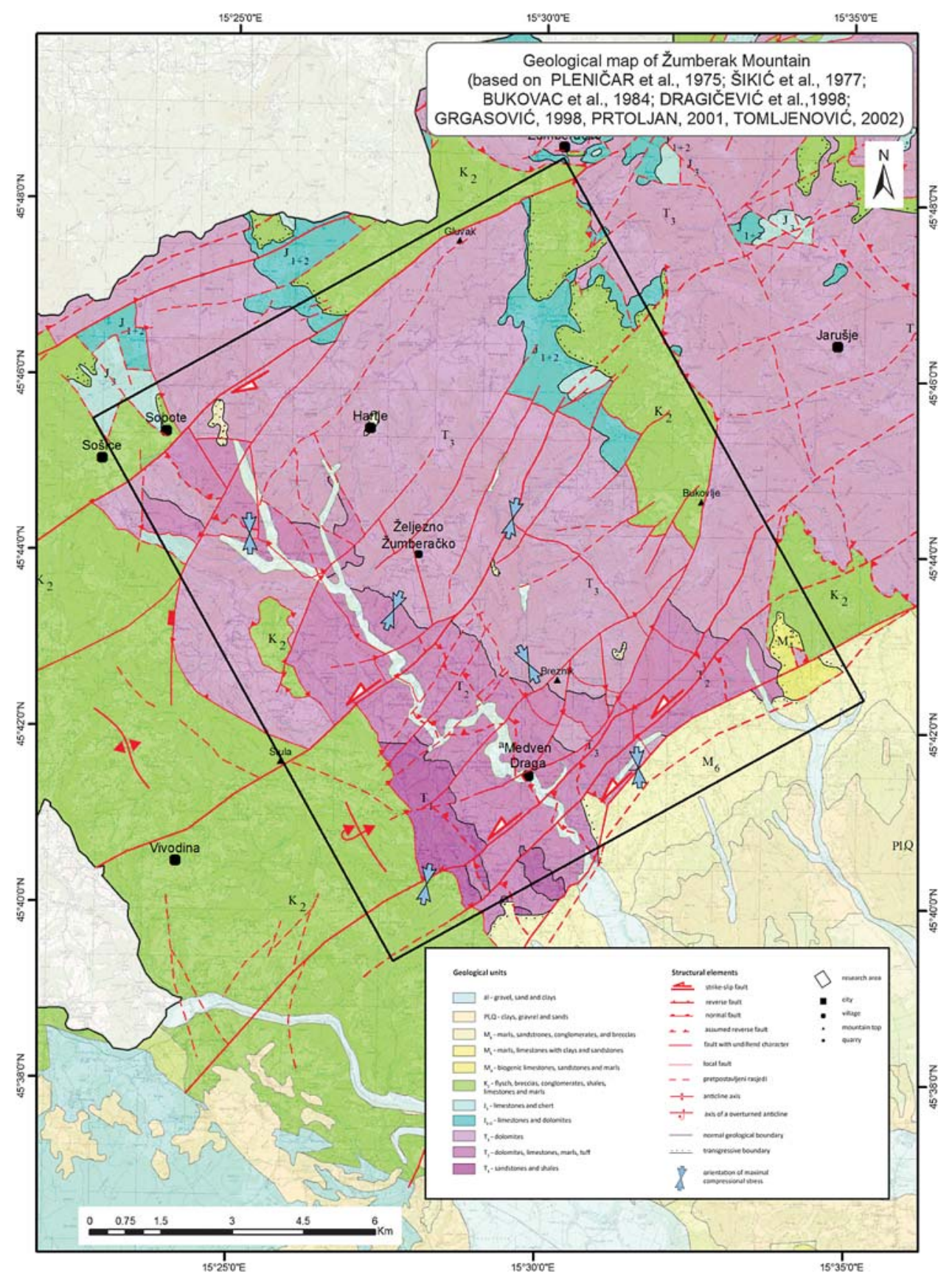

Figure 3: Geological map of Žumberak Mountain (based on Pleničar et al., 1975; Šikić et al., 1977; Bukovac et al., 1984; Dragičević et al., 1998; Grgasović, 1998; Prtoljan, 2001; Tomljenović, 2002)

\subsection{Basic mathematical background of fractal geometry and fractal dimension}

The concept of dimensions in mathematics is viewed from different points of view and there are different definitions of dimensions (Scleicher, 2007). Euclíd's and topological dimensions are finite integers $(1,2,3, \ldots)$ which roughly define space. For this study, it was necessary to look at dimensions from a different point of view. Many objects and natural phenomena can be described by $0,1,2,3$ dimensions. However Mandelbrot, 1967, 1982, noted that in nature, there are a lot of phenomena which cannot be fully defined by topological dimensions. Such examples are clouds which are not spheres, lightning which is not a straight line, mountains which are not cones, etc. (Mandelbrot, 1982). Their dimension, fractal dimension, is often described by Hausdorff's (some authors also call it Hausdorff-Besitovich's) dimension which represents the measurement of how much an object fulfills metric (Hausdorff's) space i.e. a space that can be measured by a parameter. To understand fractals and fractal dimension, it is necessary to define terms such as Hausdorff's dimension, space and dimensions: 

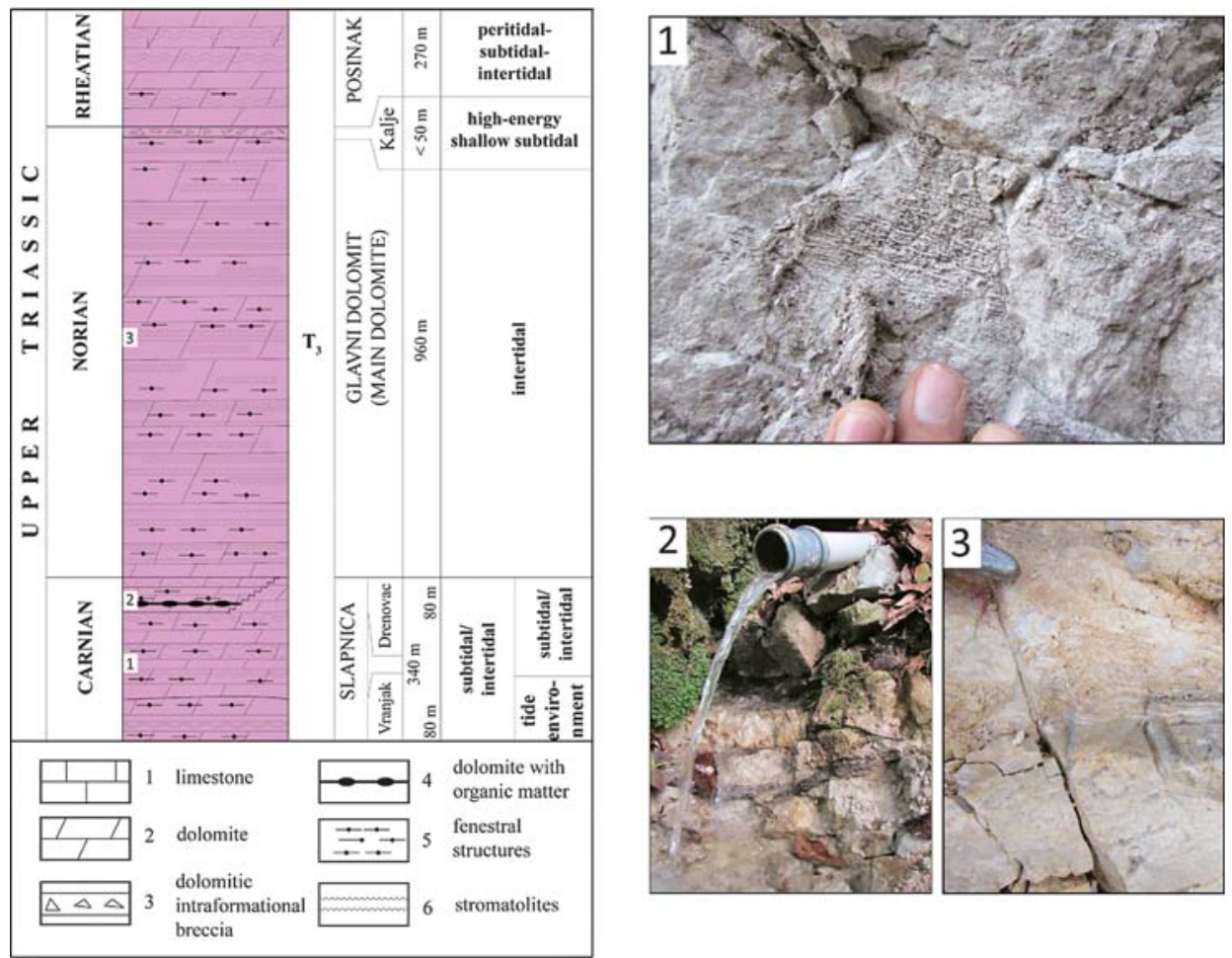

Figure 4: Geological column of Upper Triassic dolomites in Žumberak Mountain.

1) Straight-line stromatolites from the Slapnica formation. 2) Layer of coal in the Denovac unit in the Slapnica formation.3) Microwave stromatolites in the "Glavni dolomit" formation (modified after Grgasović, 1997; Grgasović, 1998).

$\delta$-overlap of a set $F$ is a countable (finite) sum of the sets $\left\{U_{i}\right\}$, with radii, $0<\left|U_{i}\right| \leq \delta$ which overlap set $F$. Let $F \subset R^{n}$ and let $s \in[0, \infty\rangle$, for every $\delta>0$, Hausdorff's dimension will be defined as:

$$
\begin{gathered}
(F)=\inf \left\{\sum_{i}^{\infty}\left|U_{i}\right|^{s}: \delta \text {-overlap of the set } F\right. \\
\text { with "spheres" of radii } \left.\left|U_{i}\right|>0\right\}
\end{gathered}
$$

The goal is to look for for all possible overlap of the set $F$ with a maximum diameter of $\delta$ and strive to minimize the sum of the s-potential of the radius (Equation 1) (Falconer, 2014). As $\delta$ decreases, the number of possible overlap decreases but the value of the infimum $H_{\delta}^{s}(F)$ increases or does not change as $\delta$ decreases and approaches the limit which strives towards zero (Falconer, 2014). This can be rewritten as (Equation 2):

$$
H^{s}(F)=\lim _{\delta \rightarrow 0} H_{\delta}^{s}(F)
$$

This limit exists for every subset $\mathrm{F}$ of the set $\mathrm{R}^{\mathrm{n}}$, although the limit value is often 0 or $\infty . H_{\delta}^{s}(F)$ is called the s-dimensional Hausdorff measure of a set F. Hausdorff's measure represents a measure of the metric space that assigns each set from $\mathrm{R}^{\mathrm{n}}$ a value from within the range $[0, \infty]$. 0 -dimensional Hausdorff's measure is the number of points in a finite set, or in an infinite set. 1-dimensional measurements of some gentle curve or line in a subset of the set $R^{n}$ is equal to the length of that curve.
So Hausdorff's measure generalizes counting, length, area and volume but it does not necessarily have to be a positive integer (Falconer, 2014). According to equation 1 , it is clear that for any arbitrary set $F \subset R^{n}$ and if $\delta<1$, $H_{\delta}^{s}(F)$ does not increase with an increase in $s$, and according to equation $1.2, H^{s}(F)$ will not increase. If $t>s$ and $\left\{U_{i}\right\}$ is $\delta$-overlapping set $\mathrm{F}$, then (Equation 3):

$$
\sum_{i}\left|U_{i}\right|^{t} \leq \sum_{i}\left|U_{i}\right|^{t-s}\left|U_{i}\right|^{s} \leq \delta^{t-s} \sum_{i}\left|U_{i}\right|^{s}
$$

so taking infima over all $\delta$ covers (Equation 3),

$$
H_{\delta}^{t}(F) \leq \delta^{t-s} H_{\delta}^{s}(F)
$$

Letting $\delta \rightarrow 0$, we see that if $H^{s}(F)<\infty$ then $H^{t}(F)=0$ for every $t>s$. The graph (see Figure 5) shows that there is a critical value s, where $H^{s}(F)$ "jumps" from $\infty$ to 0 . Hausdorff's dimension is the value at which s decreases from to 0 (see Figure 5) (Falconer, 2014).

This critical value is called Hausdorff's dimension of set $\mathrm{F}$, expressed by $\operatorname{dim}_{H} F$ and is defined for every set $F \subset R^{n}$ (Equation 5):

$$
\begin{aligned}
\operatorname{dim}_{H} F & =D=\inf \left\{s \geq 0: H^{s}(F)=0\right\}= \\
& =\sup \left\{s: H^{s}(F)=\infty\right\}
\end{aligned}
$$




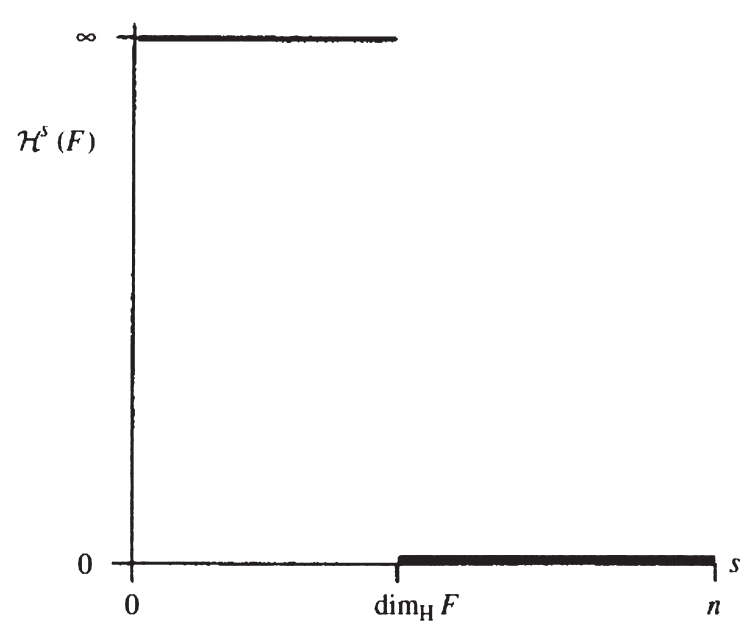

Figure 5: the dependance of Hausdorff's measures $\left(H^{S}(F)\right)$ on the dimension s (Falconer, 2014)

If the upper boundary (supremum) of an empty set is 0, then (Equation 6):

$$
H^{s}(F)\left\{\begin{array}{l}
\infty \text { if } 0 \leq s<\operatorname{dim}_{H} \\
0 \quad \text { if } s>\operatorname{dim}_{H}
\end{array}\right.
$$

If $s=\operatorname{dim}_{H} F$, then $H^{s}(F)$ can be $0, \infty$, or it can be expressed as:

$$
0<H^{s}(F)<\infty
$$

Hausdorff's dimension represents the degree to which a defined set fills a metric (with some measurable parameter) space. A point has a dimension, $\mathrm{D}=0$, a line $\mathrm{D}=1$, a plane, $\mathrm{D}=2$ and a cube, $\mathrm{D}=3$. Hausdorff's dimension is often used to describe fractal dimensions. Mandelbrot defined fractals as a set, object, of phenomena whose Hausdorff dimension (D) is greater than its topological $\left(\mathrm{D}_{\mathrm{T}}\right)$ (Mandelbrot, 1982):

$$
D>D_{T}
$$

\subsection{Deterministic and statistical fractals}

The geometry of fractals is described by power-law distribution and the potential D is represented by the fractal (Hausdorff's) dimension (Equation 7):

$$
N_{i}=\frac{C}{r^{D}}
$$

where:

$\mathrm{N}_{\mathrm{i}}=$ the number of objects, fragments characterized by the linear dimension $r$;

$\mathrm{C}=$ proportionality constant;

$\mathrm{D}=$ fractal (Hausdorff's) dimension which is calculated (Equation 8):

$$
D=\frac{\ln \left(\frac{N_{i+1}}{N_{i}}\right)}{\ln \left(\frac{r_{i}}{r_{i+1}}\right)}=\frac{\log \left(\frac{N_{i+1}}{N_{i}}\right)}{\log \left(\frac{r_{i}}{r_{i+1}}\right)}
$$

A fractal can be defined as an "irregular" fragmented geometric shape that can be divided into parts and these parts are the same between themselves and the same as the entire geometric body (the property of "self-similarity"). (Turcotte, 1997). Fractals characterized by selfsimilarity which do not depend on the scale they are bring observed in are called deterministic fractals (Turcotte, 1997). This means that the shape must be the same if we look at a fragment of the object in a mm scale or the entire object in a kilometer scale.

Natural fractals are not entirely selfsimilar. There are slight variations in self-similarity between scales, and these natural fractals are called statistical fractals (Turcotte, 1997). The variations are small enough for the object to be considered self-similar (Turcotte, 1997). Another difference between deterministic and statistical fractals is the scale in which they exist. Mathematically speaking, deterministic fractals exist in an infinite number of scales. Natural or statistical fractals appear in a particular interval of scale, i.e. the scale of occurrence is defined by an upper and lower limit (Turcotte, 1997). Natural (statistical) fractals have the following properties (Turcotte, 1997):

1) The components of the object have the same structure as the object as a whole, except in different scales when they are slightly deformed - self-similarity;

2) The shapes are often irregular and fragmented, and remain that way in all scales in which they exist;

3) Natural fractals are formed through iterative processes;

4) Fractal dimension

The concept of fractals can be applied to the statistical distribution of objects. In order for a potential powerlaw statistical distribution to be considered fractal, the number of objects $\mathrm{N}$ with characteristic linear dimension greater than $r$ must satisfy equation 7 . An increasing number of experiments indicate that most of the properties of the fractures in rocks can be described by powerlaw distribution (Vafai, 2015). The basic characteristic of fractal distribution is its independence of the scale. No characteristic scales are entered into equations 7 and 9. Mathematically, both equations can be used in infinitely large scale intervals but since natural fractals still appear limited by lower and upper limits, those limits also apply to fractal distribution (Turcotte \& Huang, 1995)

\subsection{Fractal distribution and dimension of fracture systems}

Discontinuities in rock can be observed at all scales in which the rocks appear, from the size of a micron up to and beyond a hundred kilometers (Bonnet et al., 2001; Davy et al., 2006). Quantification properties of discontinuities, faults and fractures and layered surfaces in different scales are very important in determining their role 
in fluid flow. Fault or fracture patterns often have very similar features throughout the scale range (Tchalenko, 1970; Davy \& Bour, 2006), i.e. they are characterized by the fundamental property of fractals, self-similarity.

The theory of fractal geometry (Mandelbrot, 1982) presents a good basis for understanding the connection between a set of fractures and the measurement of the processes which formed the fractures (fracturing process) (Allègre et al., 1982; King, 1983; Turcotte, 1986; Davy et al., 1995; Davy \& Bour 2006). Fractal dimensions can be estimated by (Barton, 1995):

1D data - measuring distances between fractures from the core of boreholes;

2D data - detailed survey of outcrops and quarries;

3D data - detailed geophysical survey and detailed mapping of outcrops and their combination

The fractal dimension of fracture systems can be estimated from photographs of the outcrops and samples (Barton, 1995; Verbovšek, 2009; Jie et al., 2007; Baveye et al., 1998; Davy \& Bour, 2006; Peng et al., 2011). As the photographs are characterized by two dimensions (length and width), the fractal dimension of fracture systems in photographs are in the range $1<D<2$. The applicability of fractal dimension in defining the characteristics of porosity is that it allows the extrapolation of the amount of the estimated dimensions of a higher order (from 1D to 2D, or 2D to 3D) (Mandelbrot, 1982; Bonnet et al., 2001; Barton, 1995; Verbovšek 2009; Yu, 2006), through the simple expressions (Equations 9 and 10):

$$
\begin{aligned}
& D_{2-D}=D_{1-D}+1 \\
& D_{3-D}=D_{2-D}+1
\end{aligned}
$$

This type of relationship enables the extrapolation of fractal dimensions of certain fracture systems from 2D photos into a higher order or information can be obtained on how much the fractures fill a three-dimensional space. In order to estimate the fractal dimensions of a fracture system from a photograph, it is necessary to prepare the photograph, process it, convert it into a binary image, and further enhance it as needed. The objective of this procedure is to take the photographs that were shot in the field and later converted into binary images, and generate the best possible representation of the outcrop fractures in the photographs. Preparing photographs consists of removing environmental surroundings of the photographed outcrop or the isolation of the outcrop itself for which the fractal dimension is being estimated. Unevenness on the surface of outcrops, vegetation, shadows and other items in the photograph causes interference which is often the same color and contrast as the fractures, so this should be taken into account when processing photographs. In some areas of the outcrop, fractures are faint which is caused by the fact that the fractures are filled with clay or some other such filling, crushed rock on the surface of the outcrop or a very small fracture width, resulting in very little difference in color when compared to the rest of the rock.

\subsection{Research methodology}

Three sites were selected (see Figure 6) where outcrops were surveyed in detail. For each outcrop, representative images were selected, processed and fractal dimensions were calculated for each one.

In this study, automatic algorithms were used for converting photographs into binary images using the computer programs Gimp 2 and ImageJ. The advantage of these algorithms is the processing speed and performance. However, better results are obtained through the manual processing of photographs and the manual digitalising of fractures from a photograph, which represents the next phase of research.

The fractal dimensions are estimated from the photographs using the tool "Fractal Box Counting" within the computer program ImageJ. The method used for estimating the fractal dimension is called the "box counting method" (Feder, 1988) where the photograph is covered in squares with sides of length $s$. Software for each size of square counts the squares that contain fractures N(s) (Feder, 1988; Bonnet, et al., 2001; Verbovšek, 2009). With fractals, the number of squares that contain a fracture are under the "power-law" function relationship with the size of the side of the squares, s, and fractal dimension is calculated as the slope of the linear regression of the log-log scale which best fits the input data.

The following dimensions of square side lengths were used (in pixels): 2, 3, 4, 6, 8, 12, 16, 32 and 64 and the

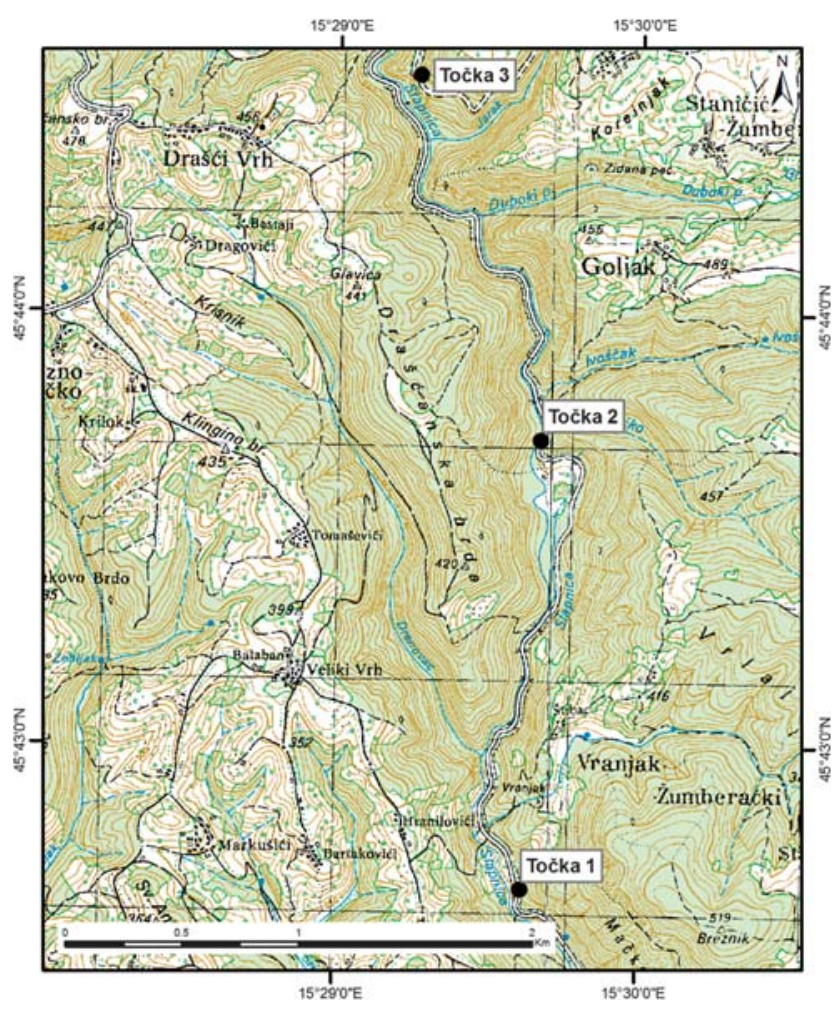

Figure 6: Locations of analysed outcrops 

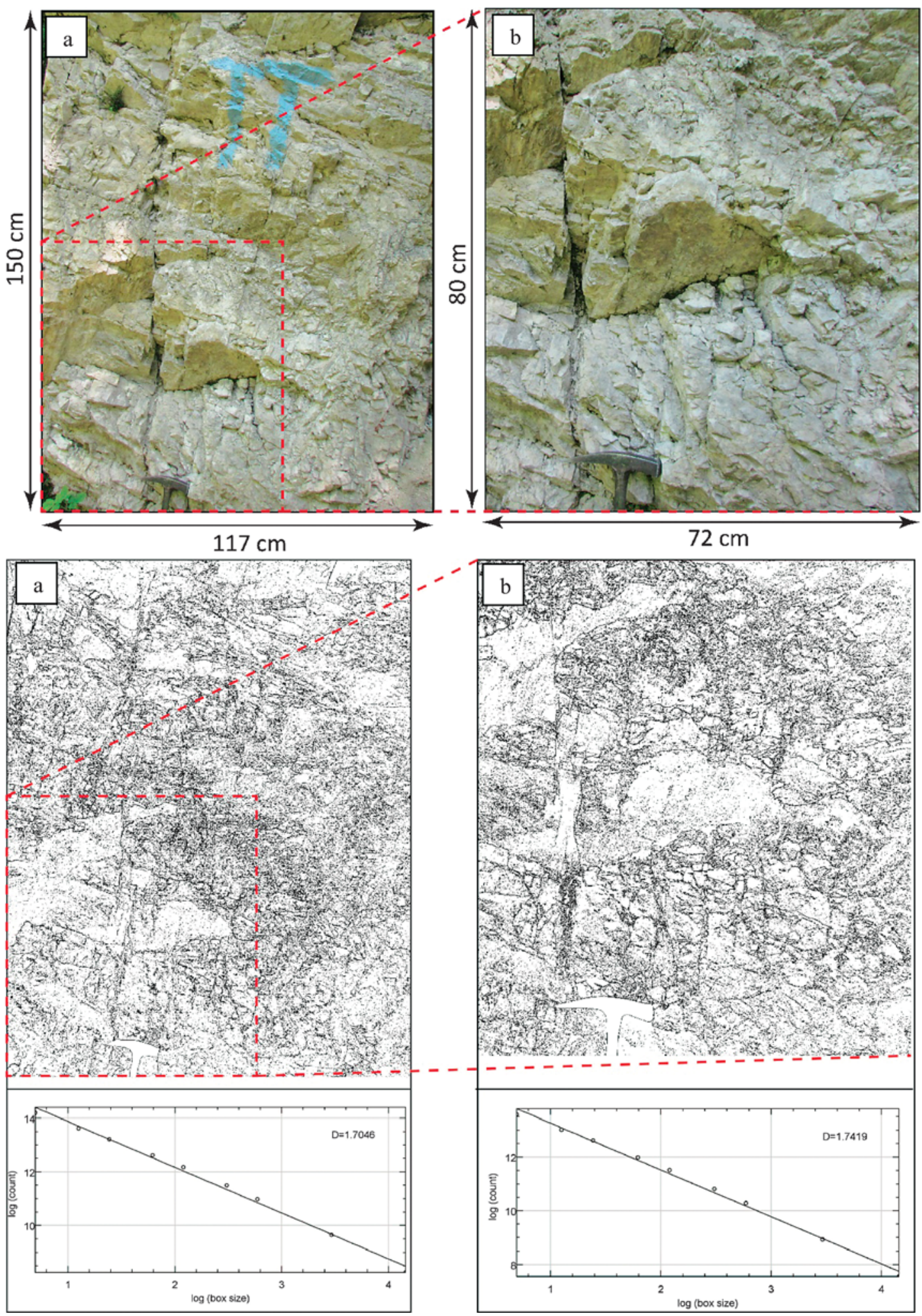

Figure 7: a) Photographs of outcrop in Pl-1; b) Binary photographs of outcrops in Pl-1 with graph of box size vs. number of boxes relation with regression line for obtaining fractal dimension by the box-counting method.

results of the processing of photographs along with the accompanying box counting diagrams can be seen in Figures 7, 8 and 9. During the investigations so far, 28 outcrops were recorded in high detail while this paper covers three representative models. The representative outcrops were chosen to illustrate various examples of the spatial distribution of fracture systems and how fractal analysis helps in their descriptions. 

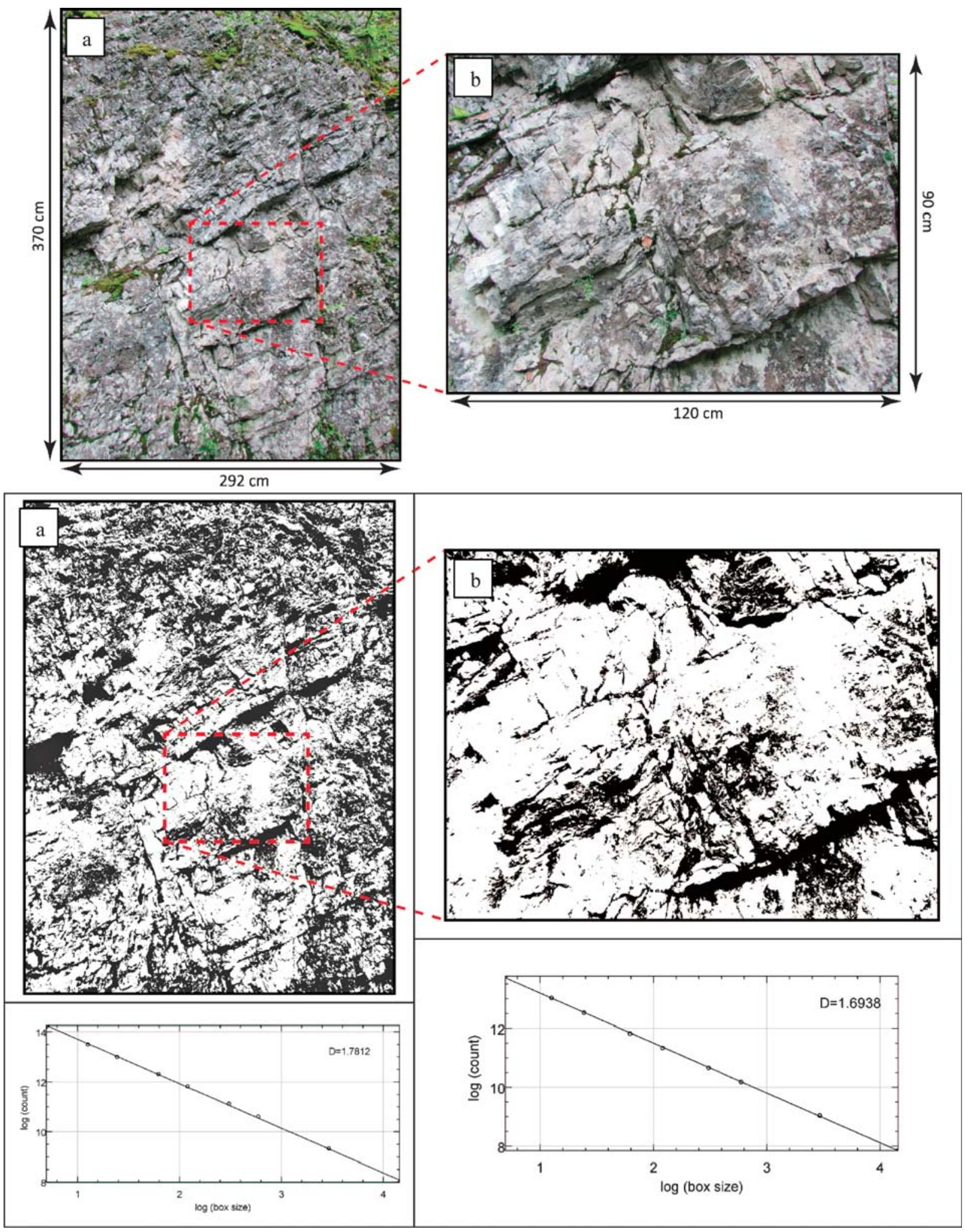

Figure 8: a) Photographs of outcrop in $\mathrm{Pl}-2$; b) Binary photographs of outcrops

in $\mathrm{Pl}-2$ with graph of box size vs. number of boxes relation with regression line for obtaining fractal dimension by the box-counting method.

Typically, images that show a larger area have less sensitivity to detail, and only major fractures can be registered, and usually, there are not many of them. The larger the scale of the outcrop photograph, the smaller the size of the captured fractures, but the number of fractures is greater which is according to the power-law function (Barton, 1995) (see Figures 7a \& 9a). Thus, outcrop photographs in a smaller scale will show a 

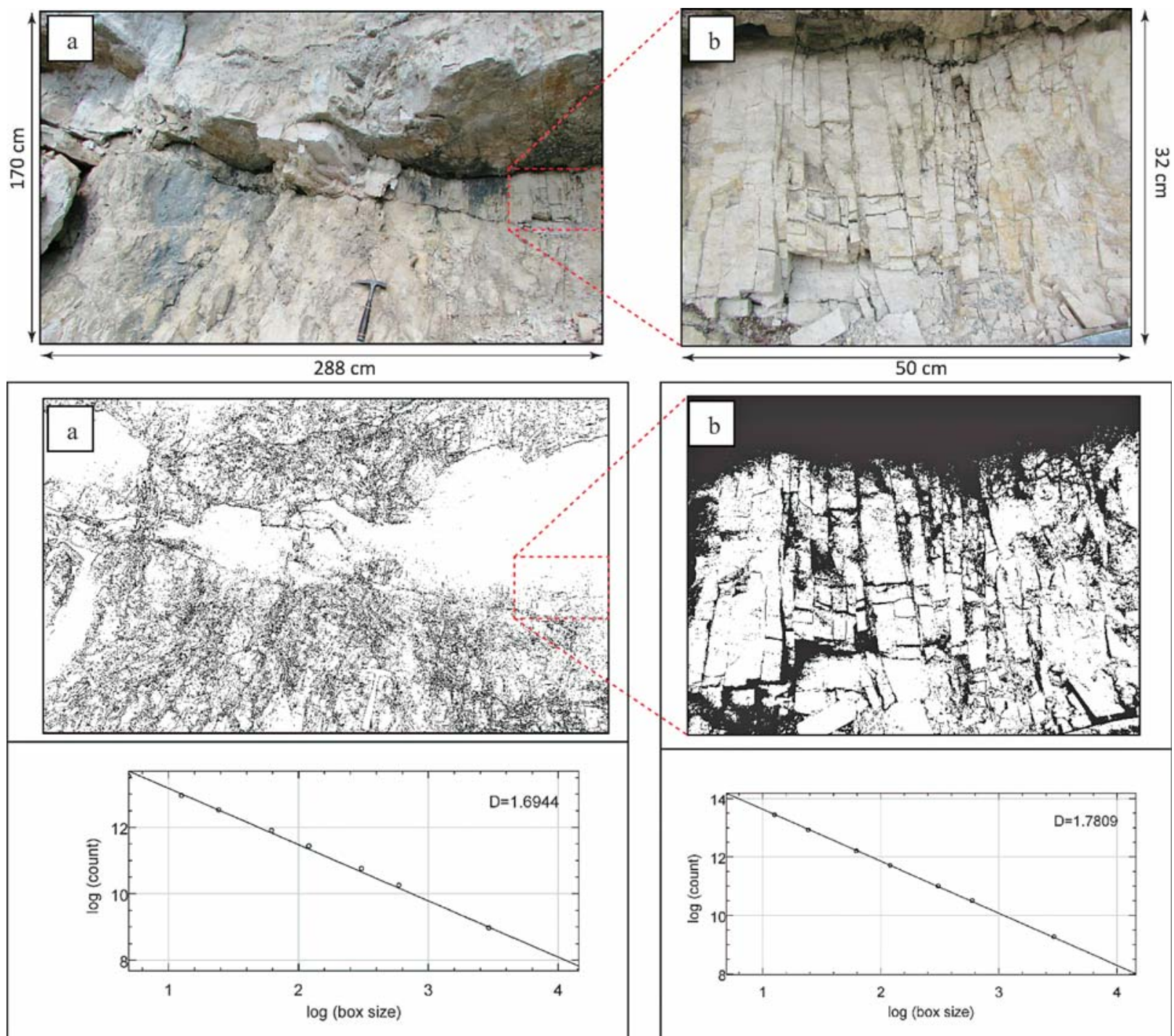

Figure 9: a) Photographs of outcrop in Pl-3; b) Binary photographs of outcrops in $\mathrm{Pl}-3$ with graph of box size vs. number of boxes relation with regression line for obtaining fractal dimension by the box-counting method.

smaller number of larger or more significant fractures, and will not include minor fractures resulting in smaller fractal dimensions of these photos (see Figures $7 \mathbf{b} \boldsymbol{\&}$ 9b). Outcrop photographs in a larger scale do not show significant fractures or show them only partially, but because of the higher resolution, they display a large number of small fractures which fill the space and thus the fractal dimension of such photographs is higher (see Figures 7 and 9). This is most often the case, and it was observed in almost all recorded outcrops.

In the outcrop in P1-1 (see Figure 7) due to a larger recorded surface and less sensitivity to detail (see Figure. 7a), a small part is not registered and so the fractal dimension of outcrops on $\mathbf{7 a}$ is $\mathrm{D}=1.70$. Since Figure $\mathbf{7 b}$ shows a more detailed part of the outcrop and a large number of small fractures are registered, the fractal dimension is slightly higher at $\mathrm{D}=1.74$.

A similar situation can be seen for the outcrop in Figure 9 where the fractal dimension is greater, $\mathrm{D}=1.78$ in
Figure 9b which shows a larger scale than in Figure 9a, where $\mathrm{D}=1.69$. At Pl-3, there is a very clear difference in resolution because the fractures in the square in Figure 9a are barely visible while the same fractures are shown in great detail in Figure 9b.

Usually, fractal dimensions of an outcrop are greater when moving from a smaller to larger scale. The exception to the rule is the example of Pl-2 (see Figure 8). The major discontinuities are layered surfaces on which smaller fractures end. However, not all tectonic layers are fractured in the same manner and so there are some areas with relatively few fractures (see Figure 8b). The fractal dimension on the photograph of the whole outcrop (see Figure 8a) is D = 1.78, while the smaller part of the outcrop shown in a larger scale (see Figure 8b) has a fractal dimension of $\mathrm{D}=1.69$. For fractal analysis in a larger scale, a relatively compact part of the outcrop was selected with less fractures and this resulted in a lower fractal dimension. This example, and its compari- 
son with Pl-1 and 3, is important in order to understand how the fractal dimension of fracture systems depends on their distribution.

Each of these examples shows a different distribution of fractures due to the varying range of scale on the photographed images. If the distribution of fractures were deterministic fractals, the dimensions on all the photographs of each outcrop would be equal. However, the distribution of fractures are a natural fractal, with certain variations in self-similarity but the photographs themselves have some limitations (resolution, shadows, coverage of the outcrops, etc.) which causes deviations from the "real" value. The values in this analysis range in the interval between 1.69-1.78. The results of the analyses in Figures $7 \mathbf{b}, \mathbf{8 a}$ and $9 \mathbf{b}$ should be considered realistic results where the fractals were mostly around 1.78, which coincides with the results of fractal analysis of the Middle and Upper Triassic dolomites from Slovenia (Verbovšek, 2009). All values can be extrapolated in higher order by equation 3.11. By this extrapolation, fractal dimension from photographs (2D) can be extrapolated in three-dimensional space (see Table 1).

Table 1: Fractal dimension estimated from binary photographs (Fdim photo) and extrapolated fractal dimension to higher order (Fdim extr)

\begin{tabular}{|l|c|c|}
\hline Placemark & Fdim photo & Fdim extr \\
\hline \multirow{2}{*}{ PL-1 } & 1.7086 & 2.7086 \\
\cline { 2 - 3 } & 1.7419 & 2.7419 \\
\hline \multirow{2}{*}{ Pl-2 } & 1.7812 & 2.7812 \\
\cline { 2 - 3 } & 1.6938 & 2.6938 \\
\hline \multirow{2}{*}{ Pl-3 } & 1.6944 & 2.6944 \\
\cline { 2 - 3 } & 1.7809 & 2.7809 \\
\hline
\end{tabular}

\section{Conclusion}

These three examples show how fracture systems of the Upper Triassic dolomites of Žumberak are not deterministic fractals, i.e. the distribution of fracture systems is not ideally self-similar in all scales. If the distribution of the analyzed fracture systems were deterministic fractals, the fractal dimensions of fracture systems in all scales would be the same. Differences in the fractal dimensions are caused by numerous factors:

- Fracture systems are natural fractal, with some differences in different scales;

- Photographs do not represent a completely realistic image of the outcrop i.e. fracture systems of the outcrop. Ideally, all fractures would be in one photograph but that is impossible because of image resolutions.

- Photographs of parts of the outcrop in a larger scale (see Figures $7 \mathrm{~b}, 8 \mathrm{~b}$ and $9 \mathrm{~b}$ ) have a higher resolution but larger fractures and fractures in the peripheral parts are not completely displayed, i.e. these fractures are only partially shown in the photographs. In addition, photographs in a larger scale may show an unrealistic image of an outcrop, as in Pl 2 where Figure 8b shows only part of the layer which is compact and so the fractal dimension in that area is smaller than the rest.

- It would be better to manually process fractures on photographs because the automatic extraction of fractures by using simple algorithms during the conversion of photographs into binary images is subject to error. This occurs because the computer distinguishes fractures based on the difference in color between the rocks and fractures and here various interferences can contribute: a relatively low resolution of photographs, clay and other fillers in the fractures, small thickness of the fractures, shadows and others.

The obtained fractal dimensions are in the range 2,682,78 which is very similar to the results of fractal analysis in similar dolomites in Slovenia (Verbovšek, 2009). Regardless of the listed deficiencies, fractal dimensions which are determined in this manner give an indicative picture of the spatial distribution of fractures and fracture systems. A higher fractal dimension (closer to dimension 3) indicates a higher density of the occurrence of small fractures around several larger ones. A smaller fractal dimension (closer to dimension 2) indicates the dominance of a small number of larger fractures. In further research, more outcrops should have fractures extracted manually. It would be interesting to compare the results of fractal analyses of Upper Triassic dolomites from other sites. The fractal dimension can be in a DFN ("discrete fracture network" model) as an input parameter if the distribution of fractures and their characteristics are modeled on the basis of the power-law function.

The research shows that fractal dimension is a significant parameter in the description of the distribution of fracture systems in the Upper Triassic dolomites. With a large number of analyses, an interval value of fractal dimensions of Upper Triassic dolomites can be achieved. Then it will be possible to assess the distribution of fractures and fracture systems in the deep structures that may contain geothermal water or hydrocarbons.

Acknowledgements: The authors would like to thank Prof. Emeritus Darko Mayer for his full support during all work phases. Also we would like to thank Assoc. Prof. Anja Vrbaški on constructive suggestions.

\section{References:}

Agosta, F. \& Tondi, E. (2010): Faulting and fracturing of carbonate rocks: New insights into deformation mechanisms, petrophysics, and fluid flow properties. Journal of Structural Geology 32 (2010), 1185-1186.

Allègre,C. J., Lemouel,J. L. \& Provost,A. (1982): Scaling rules in rock fracture and possible applications for earthquake prediction. Nature, 297, 47-49. 
Antonellini, M. \& Mollema, P. (2000): A Natural Analog for Fractured and Faulted Reservoir in Dolomite: Triassic Sella Group, Northern Italy. AAPG Bulletin, V. 84, No. 3. 314-344.

Antonellini, M. \& Mollema, P. (2016): Heterogenesis in fractured aquifers: Examples from outcrops and implications for fluid flow modelling. EGU General Assembly 2016, held 17-22 April, 2016 in Vienna Austria, poster, p.1954.

Barton, C.C. (1995): Fractal Analysis of Scaling and Spatial Clustering of Fractures. In: Barton, C.C. and La Pointe, P.R. (eds.), Fractals in the Earth Sciences. Plenum Press, New York, p. 141-178

Bauer, H., Schrockenfuchs, T.C. \& Decker, K. (2016): Hydrogeological properties of fault zones in karstified carbonate aquifer (Northern, Calcareous Alps, Austria). Hydrogeol. J (2016) 24:1147-1170.

Baveye, P., Boast, C., Ogawa, S., Parlange, J.Y. \& Steenhuis, T. (1998): Influence of image resolution and thresholding on the apparent mass fractal characteristics of preferential flow patterns in field soils. Water resources research, vol. 34, no 11, pp. 2783-2796.

Bonnet, E., Bour, O., Odling,N.E., Davy, P., Main, I., Cowie, P. \& Berkowitz, B. (2001): Scaling of fracture system sin geological media. Reviews of Geophysics, 39, 3 / August 2001, 347-383.

Brkić, Ž., Kuhta, M. \& Singer, D. (2002): Geological and hydrogeological basis of Žumberak and Samoborsko gorje nature park (in Croatian). Fond stručne dokumentacije Parka prirode „Žumberak-Samoborsko gorje“, Slani Dol.

Bukovac, J., Poljak, M., Šušnjar, M. \& Čakalo, M. (1984): Osnovna geološka karta SFRJ, 1:100 000, list Črnomelj L 33-91, (Basic geological map of SFRY, sheet Črnomelj). Geološki zavod Zagreb i geološki zavod Ljubljana, Savezni geološki zavod Beograd (in Croatian).

Davy, P. \& Bour, O. (2006): Flow in multiscale fractal fracture networks. Geological Society London Spetial Publications, 2006. DOI: 10.1144/GSL.SP.2006.261.01.03.

Davy, P., Hansen, A., Bonnet, E. \& Zhang, S.-Z. (1995). Localization and fault growth in brittleductile systems. Implications to deformations of the continental lithosphere. Journal of Geophysical Research, 100, 6281-6294.

Dragičević I., Prelogović, E., Pavelić, D., Vranjković, A., Pavičić, I. \& Šipek, S. (2014): Hidrogeološka potencijalnost gorskih i prigorskih vodonosnika sjeverne Hrvatske (Hydrogeological potential of mountain aquifers in north Croatia). Stručni elaborat, 235 str. RGNF, Sveučilište u Zagrebu, Zagreb (in Croatian).

Dragičević, I., Blašković, I., Mayer, D., Žugaj, R. \& Tomljenović, B. (1997): Gorski i prigorski vodonosnici sjeverne Hrvatske (izvješće o radovima u 1997. godini) (Mountain aquifers in north Croatia). Fond stručne dokumentacije RGNF, Zagreb (in Croatian).

Falconer, K. (2014): Fractal Geometry, Mathematical Foundations and Applications. Third edition, 368 str, John Wiley $\&$ Sons LTD.

Feder, J. (1988): Fractals. Plenum Press, New York, 283.

Frangen, T. (2013): Determining the characteristics of karst aqufer on southwestern Žumberak area using quantitative tracing in various hydrological conditions (in Croatian). PhD Thesis. RGNF, University of Zagreb, 204 str.

Grgasović, T. (1997): Upper Triassic biostratigraphy and algae from Žumberak (Croatia). - Geologia Croatica, Zagreb, 50/2, 201-214, 1 fig., 2 pl.

Grgasović, T. (1998): Stratigrafija gornjotrijaskih naslaga Žumberka (Upper Triassic Stratigraphy of Žumberak). Magistarski rad. PMF, Sveučilište u Zagrebu, 134 p, Zagreb (in Croatian).

Jie, Z., Ruirui, Z., Buyuan, H. \& Bai, S. (2007): Fractal Image Processing and Analysis by Programming in MATLAB. Proceedings of the 8th WSEAS Int. Conference on Mathematics and Computers in Biology and Chemistry, Vancouver, Canada, June 19-21, 2007.

King, G. (1983): The accommodation of large strains in the upper lithosphere of the earth and other solids by self-similar fault-system. Pure and Applied Geophysics, 12, 761-915.

Mandelbrot, B (1967): How long is the coast of Britain? Statistical self-similarity and fractional dimension. Science: 156, 1967, 636-638.

Mandelbrot, B (1982): The Fractal Geometry of the Nature. 468 str. W.H. Freeman and Company, New York.

Pamić, J. \& Tomljenović , B. (1998). Basic geologic data from the Croatian part of the Zagorje-Mid Transdanubian zone. Acta Geologia Hungarica, Budapest, 41, 389-400.

Panza, E., Agosta, F., Zambrano, M., Tondi, E., Prosser, G., Giorgioni, M. \& Janiseck, J.M. (2015): Structural architecture and Discrete Fracture Network modelling of al layered fractured carbonates (Altamura, Fm., Italy). Ital. J. Geosci. (Boll. Soc. Geol. It.), Società Geologica Italiana, Roma 2015, Vol. 134, No. 1 (2015), 1-40.

Pavičić, I. (2014): Regionalni geološki i hidrogeološki odnosi u području Žumberka i Samoborskog gorja s posebnim osvrtom na zalihe podzemnih voda (Regional geological and hydrogeological settings of Žumberak and Samobor Mountain with special emphasis on groundwater reserves). Diplomski rad, Rudarsko-geološko-naftni fakultet, Sveučilište u Zagrebu (in Croatian).

Peng, R.D., Yang Y.C., Ju Y., Mao, L.T. \& Yang, Y.M. (2011): Computation of fractal dimension of rock pores based on gray CT images. Chinese Sci Bull, 2011, 56: 3346-3357.

Pleničar, M. \& Premru, U. (1977): Osnovna geološka karta SFRJ, 1:100 000, Tumač za list Novo Mesto L 33-79 (Basic Geological Map of SFRY - sheet Novo Mesto), Geološki zavod Ljubljana, Savezni geološki zavod Beograd (in Slovenian).

Prtoljan, B. (2001): Relationships of thrust-fold and horizontal mechanism of the Mountain Žumberak part of the Sava nappe in the northwestern Dinarides, West Croatia. Acta Geologica Hungarica, Budapest, 44, 67-80.

Rusticheli, A; Tondi, E., Agosta, F., Celma Di, C. \& Giorgioni, M. (2013): Sedimentologic and diagenetic controls on pore-network characteristics of Oligocene-Miocene ramp carbonates (Majella Mountain, central Italy). AAPG Bulleting, v97, no.3 (March 2013), pp. 487-524.

Scleicher, D. (2007): Hausdorff dimension, its properties, and its surprises. American Mathematical Monthly 114 (2007), 509-528. 
Šikić, K., Basch, O. \& Šimunić, A. (1977): Osnovna geološka karta SFRJ, 1:100 000, list Zagreb L 33-80, (Basic Geological Map of SFRY - sheet Zagreb)Institut za geološka istraživanja Zagreb, Savezni geološki zavod Beograd (in Croatian).

Tomljenović, B. (2002): Strukturne značajke Medvednice i Samoborskog gorja (Structural settings of Medvednica and Samobor Mountain). Doktorska disertacija, RGNF, Sveučilište u Zagrebu, p. 208. Zagreb (in Croatian).

Turcotte, D.L. \& Huang, J. (1995): Fractal Distributions in Geology, Scale Invariance, and Deterministic Chaos. Chapter 1 iz BARTON, C. \& LA POINTE, P.R. (1995): Fractals in the Earth Sciences. 265 str. Springer Science+ Business Media, LLC, New York.

Turcotte, D.L. (1997): Fractals and Chaos in Geology and Geophysics. Second edition, 398 str. Cambridge University Press, New York.
Verbovšek, T. (2009): Extrapolation of fractal dimensions of natural fracture networks from one to two dimensions in dolomites in Slovenia. Geosciences Journal. Vol 13, No. 4, p 343-351.

Vujnović, T. (2010): Hidrogeološke značajke parka prirode "Žumberak-Samoborsko gorje" (Hydrogeological characteristics of the "Žumberak-Samoborsko gorje" nature park). Doktorska disertacija. RGNF, Sveučilište u Zagrebu. $180 \mathrm{p}$ (in Croatian).

Yu, B. (2005): Fractal dimensions for multiphase fractal media. Fractals, Vol. 14, No. 2 (2006), 111-118.

Zambrano, M., Tondi, E., Korneva, I., Panza, E., Agosta, F., Janiseck, J.M. \& Giorgioni, M. (2016): Fracture properties analysis and discrete fracture network modelling of faulted tight limestones, Murge Plateau, Italy. Ital. J. Geosci. (Boll. Soc. Geol. It.), Vol. 135, No. 1 (2016), Società Geologica Italiana, Roma 2016., 55-67.

\section{SAŽETAK}

\section{Fraktalna analiza pukotinskih sustava u gornjotrijaskim dolomitima u području Žumberka, Hrvatska}

U ovome radu prikazani su rezultati fraktalne analize pukotinskih sustava u gornjotrijaskim dolomitima Žumberka. Mehanička svojstva stijena zajedno s dijagenetskim i strukturnim procesima rezultirali su pukotinskim sustavima koji se mogu opisati kao fraktali. Prirodni fraktali neovisni su o mjerilu u određenome intervalu mjerila u kojemu se pojavljuju. Raspodjela pukotina može se tada opisati raspodjelom power-law i fraktalnom dimenzijom. Fraktalna dimenzija mjera je kojom određeni objekt ispunjava prostor. Može se procjenjivati iz fotografija izdanaka koje su pretvorene u binarne fotografije gdje bijela boja predstavlja pukotine/stijenu, a crna stijenu/pukotine. Fraktalna dimenzija pukotinskih sustava tada se može procjenjivati na temelju metode box-counting. U ovome radu prikazani su rezultati fraktalne analize triju izdanaka. Rezultati su vrlo slični dosad objavljenim rezultatima fraktalne analize sličnih dolomita iz Slovenije. Procijenjene fraktalne dimenzije kreću se u intervalu 2,69-2,78, a ovise o raspodjeli pukotinskih sustava na izdanku. Niže vrijednosti upućuju na veći utjecaj manjega broja velikih pukotina. Veće vrijednosti fraktalnih dimenzija upućuju na ujednačenu raspodjelu većega broja manjih pukotina. Fraktalna dimnezija vrlo je važan parametar u opisu pukotinskih sustava jer predstavlja mjeru kako su pukotine raspoređene na izdanku. Može se koristiti i pri izradi diskretnih modela pukotinskih sustava (engl. Discrete Fracture Network - DFN) ako se raspodjela pukotina modelira s raspodjelom power-law.

\section{Ključne riječi}

pukotinski sustavi, trijaski dolomiti, fraktalna dimenzija, Žumberak 